\title{
The Relationship between the Typical Errors in the Translation of Business Idioms and their Lexicographical Treatment
}

\author{
Esther Fraile Vicente \\ University of Valladolid \\ frailes@lia.uva.es
}

\begin{abstract}
This essay is based on the complexity involved in the translation of English business idioms into Spanish, due to the fact that these linguistic constructions are created with metaphors and based on associations of meaning that have not yet been studied sufficiently. By performing a translation experiment with my students, some conclusions are drawn regarding the difficulties inexperienced translators face and how dictionaries should cope with them. It is suggested that, most general and specialized dictionaries do not offer exact translation equivalents for idioms, but present versions that either belong to a different language level, show a lost of semantic content, have a different frequency, are archaic or erroneous. To solve these limitations, the lexicographical resources should not only include idioms as lemmas, but also offer more syntactic-semantic information with them and to structure it more systematically.
\end{abstract}

\section{Introduction: Specialized Translation}

I think that a good starting point would be to define languages for special purposes (LSPs) ${ }^{1}$ in relation to the general language (GL), to establish the kind of difficulties the translator should overcome in specialized translation and the skills he should possess to carry out the task satisfactorily.

The specialized languages constitute pragmatic sets of the global language (which is comprised of both the GL and all the sublanguages) that show continuous exchanges among 
them and with the common language. The general language presents a neutral register, its units are used in non marked situations and it exhibits a maximum formal variation at all levels, only restricted by the comprehension limits of its users. On the other hand, the specialized languages constitute a set of subcodes, partially coincident with that of the common language, and are characterized by some specific peculiarities such as the subject matter involved, the level of abstraction of the message, the type of user, his or her intentions, the communicative situation, the discourse linguistic particularities... As a result, they can be considered "marked" by all these determining factors (Cabré Castellví, 1993: 128-129). The previous definition reveals that variation takes place into the GL, but also into the special languages, that LSPs show some elements traditionally associated to general communication such as metaphors and other aesthetic effects (Mayoral Asensio, 1999: 9).

The best way to translate an LSP into another language is to take into account all the previous elements as these will determine the terminology (and phraseology) to use:

- In the first place, the translator should be able to understand the complex conceptual structure of the subject field concerned, that each terminological unit corresponds to a cognitive knot inside a specific domain and the sum of all those knots, connected by specific relationships (cause-effect, whole-part, contiguity...), constitutes the conceptual system of that field (Cabré Castellví, 2004: 97-98).

- The level of abstraction of the text will determine the terminology to use: the more abstract the message, the more precise the terms; the grammatical, syntactical and semantic selection will be more rigid; the number of users more restricted and the lexical units and rules more international (Tarantino, 1991: 49).

- Depending on the type of user, translators would employ the terms with a higher or lower degree of specificity: while expert to expert communication involves the precise use of highly-specialized terms, and paraphrases are reserved to explain neologisms or redefine existing concepts; expert to initiate communication shows a lower density of specialized terms, whose meaning is frequently explained in an accessible and sometimes imprecise way (Pearson, 1998: 36). These trends foster the use of semitechnical vocabulary: lexical units from the general language, or related specialized disciplines, which acquire a new meaning in another LSP through metaphorical processes (Cabré Castellví 1993 and 1994).

- The LSPs fulfil mainly a communicative function that stands out against other secondary functions (poetic), they choose the more economical expression and make use of linguistic resources that transmit information objectively and impersonally: textual formulas such as description, definition, classification, enumeration, argumentation, citation, reference; together with the use of verbs in the present tense, the first person of the plural, short sentences, passive verbs and noun phrases. Nevertheless, the specialized languages also show a poetic function, the specialized texts can be 
redundant, emotive, metaphorical and ambiguous, and the translator should take this into consideration.

- The transfer of a specialized text requires knowledge of its composition rules, typical structures and more suitable terminological resources. A specialized text is a sum up of units of knowledge pertaining to different levels of lexicalization (terminological units, phraseological units and specialized contexts), that present an important index of formal variation. In fact, the higher the specialization of the text, the more opaque, dense and precise the terminology (Cabré Castellví, 2004: 98 and 123).

General translation poses problems of a communicative, cultural and cognitive nature, but mainly of a linguistic character. Technical translation causes the same kind of difficulties, but mainly of a terminological nature (Lerat, 1997: 103):

- A translator may not be familiar with a lexical, terminological or phraseological unit, its meaning, grammatical use or pragmatic value in the specialized field.

- If the construction does not appear in the dictionary, the translator may not know whether the target language possesses a lexicalized unit semantically and pragmatically equivalent to that used in the original text.

- He may ignore whether the units offered by the bilingual specialized dictionary are suitable for their translation.

- He may be unsure about which translation equivalent he should choose from the different alternatives offered by the dictionary (Cabré Castellví, 2004: 117).

To overcome the previous drawbacks, the specialized translator should combine quite different skills: the technical knowledge of a particular field (cognitive competence); a deep linguistic proficiency in both the source and target languages, which includes lexical, phraseological and terminological units (linguistic competence); and a documentary competence, on information retrieval and computerised tools available, which allows him to find the information he needs easily and quickly. Thus, the LSP translator is at the same time an editor, sometimes a jurist, economist or scientist and, mainly, a documentary maker and a terminologist (Gallego Pelegrín, 2004: 20).

Nowadays, a flexible prototypology of the languages for special purposes is recognized, which considers these languages hybrid forms with a mixture of characteristics and unclear limits, and just detects the small linguistic or stylistic differences between them. Thus, business English is depicted as an intermediate reality that fluctuates between the creativity, innovation and variable interpretation of the literary genres and the fossilized expressions and conformity of legislation (Bhatia, 1995: 459-461).

Unlike other LSPs, business discourse shows a high degree of emotive meaning, abstract processes like metaphors that bring about a great number of idioms and figurative expressions. Several authors have pointed out that economics texts are heavily metaphorical (McCloskey, 1983: 481-517 y Mason, 1990: 16-28) as it is shown by widely used 
constructions such as human capital, falling unemployment, demand expansion and contraction, credit flows, accelerating growth rates, liquidity squeeze. As a result, the language of economics may not be literal and more difficult for the beginner to understand (Charteris-Black \& Ennis, 2001: 251-252).

This article focuses on the translation of those business idioms and assumes that, if the specialized lexicographical resources want to respond to the needs of users like translators, they should improve their treatment of these expressions.

\section{The translation of metaphor and business idioms}

This piece of writing is related to a recurrent issue in Translation Studies, metaphor translation, which is applied to economics, a field whose figurative idioms have not yet been investigated in depth. However, a detailed description of the role of metaphor in business English should be carried out, due to the quantitative and qualitative importance that this rhetorical figure has in the formation of terms in that discourse, mainly specialized phraseological units (also called terminological phrasemes, Meyer \& Mackintosh 1994, Montero Martínez 2002).

The complexity involved in the translation of English business idioms into Spanish is already suggested by the traditional definition of an idiom as a formally complex linguistic expression whose total meaning may be different from that of the individual words that make up the expression (Lipka, 1990: 96). Idioms show an abstract meaning, a high semantic density that has to be transferred to another relatively short figurative expression in Spanish. Besides, these linguistic constructions are created with metaphors and other rhetorical figures, based on associations of meaning that have not yet been studied sufficiently.

The notion of metaphor and the function attributed to this figure have evolved along history:

- The word metaphor, of Greek origin, means "transposition" and designates a figure that applies the name of an object to another with which it bears a kind of similarity. In that way, traditionally, metaphor has been attributed an aesthetic function and has been considered a simple ornament, an amusing comparison which does not reflect the truth (Plato, Aristotle, Descartes, Hobbes, Leibniz, Hume...).

- Nowadays, the classic theories (Nida \& Taber 1969, Dagut 1987, Newmark 1998, Vázquez Ayora 1977, Van den Broeck 1981, Mason 1982) still consider metaphor an aesthetic resource that creates similarity, but the functionalist approach (Snell-Hornby 1988, Rabadán Álvarez 1991) and the Cognitive Semantics (Lakoff 1987, Johnson 1987, Lakoff \& Johnson 1980, Charteris-Black 2000) emphasize its dual nature, both aesthetic and cognitive, as a resource that allows to talk and think about abstract concepts and phenomena (Samaniego Fernández, 1995: 107). Metaphors focus our attention upon particular aspects of a thing that we might otherwise overlook and, in 
doing so, they also deflect our attention from other aspects so that they help us construct our perceptions of reality (Young, 2001: 607). The traditional notion of metaphor has been substituted by the idealized view of the conceptual metaphor: the common conceptual base which motivates different linguistic metaphors and exists at a deeper level connecting two otherwise unrelated semantic fields (Charteris-Black \& Ennis, 2001: 251). Any classification of the linguistic metaphors should start from the types of conceptual metaphors (Boers, 2000: 146).

- Metaphor translation has been treated by Nida \& Taber (1969), Newmark (1982), Vázquez Ayora (1977), Van der Broeck (1981), Larson (1989), Toury (1995), Dobrzynska (1995) and Kurth (1999) amongst others. They all practically agree that there are three main possibilities to translate a metaphor (Dobrzynska, 1995: 599): To use a total or partial equivalent of the original metaphor (the same image), to look for another metaphorical expression with a similar sense (but probably a different image), and to substitute an untranslatable metaphor by an approximate literal paraphrase.

The current motion of metaphor is that it plays a central role in defining and organizing both everyday (Lakoff \& Johnson, 1980: 39) and scientific realities (Henderson, 1994: 147-157). In the same way, metaphor is recognized as the most important rhetorical procedure of business discourse, which perceives the world as an abstract complex model that is explained thanks to the concrete images of metaphors (McCloskey, 1998: 12). Nevertheless, the role of metaphor in economics has not been treated in depth:

- English-Spanish cognates are common in many technical fields and economics is no exception. This trend can be extended beyond single words to embrace metaphors. To date, nevertheless, it is still hoped that a contrastive analysis of the metaphorical systems of English and Spanish be carried out, investigating the extent to which there are conceptual metaphors which can account for a range of similar surface metaphors in financial reporting in both languages. In this respect, Charteris-Black \& Ennis (2001: 253-260) have discovered that the etymological and cultural proximity of English and Spanish reflects similar conceptual metaphors with minor linguistic differences: According to the authors, on the one hand, metaphors occur with a higher frequency in Spanish financial texts ${ }^{2}$. On the other hand, there is an interaction between culture and language at the level of linguistic metaphor which, in the case of English, shows an influence of a nautical tradition resulting from its island history ${ }^{3}$; and, in the case of Spanish, an influence of a strong concern with psychological state, possibly resulting from the socio-cultural influence of religion.

- The existence of cognate metaphors on the conceptual and linguistic levels (Deignan et al., 1997: 43-51) implies that these two languages may make the same semantic links so that the metaphorical expressions of one of them would correspond to "literal" translations in the other. In this way, Fuertes Olivera \& Samaniego Fernández (1998), 
Fuertes Olivera \& Velasco Sacristán (2001b), Fuertes Olivera \& Pizarro Sánchez (2002) have studied the translation of business metaphors, emphasizing the aesthetic and cognitive function of this figure which brings about some idioms which can be considered terms. The authors defend, in most cases, the literal translation of the more innovative business metaphors ${ }^{4}$ because it keeps the double function of the figure: as a conceptual tool that creates similarities between two contexts, and as an aesthetic resource that revitalizes the metaphor and contributes to the development of the business terminology.

- Fuertes Olivera \& Samaniego Fernández (1998: 41-45) have observed that the meaning of many business idioms is motivated by a small set of traditional symbols or metaphors that refer to a few well-known categories (machines, liquids, human body, everyday life, animals, plants, colours, medicine, war, sports, games). This fact implies that it would be possible to predict the figurative meaning of these idioms. This can be seen in one of my previous works (Fraile Vicente 2005), in which I collected two groups of conceptual metaphors that can be used to describe the conceptual structure of economics and the meaning of its idioms, both in English and Spanish. These metaphors give a certain power to the economist to vary the extent to which predictions and control are represented as possible: Animate metaphors are used to describe economy (growth, depression) and economic organisations (parent/ sister company) as under the control of experts, whereas inanimate metaphors describe market movements (rebounds, slides) as beyond human control (Charteris-Black, 2000: 149 y 163).

A translation test of an economics extract was used, completed with my own translation students, to prove that there is a close relationship between the typical errors inexperienced translators make when faced to business idioms, and the gaps in the lexicographical treatment of these units due to, for example, dictionary entries not taking into account conceptual metaphors in the description of the linguistic ones.

\section{The translation test}

I used an intermediate level business passage that could be translated in a one hour session (see appendix I). I gave it to a group of 35 students from second year Translation and Interpreting studies as I feel that they are the best candidates to illustrate the average translation problems that a new translator can find before a specialized text.

The sample text was specifically selected because it contains a higher frequency of idioms than what is expected from these expressions ${ }^{5}$, and shows examples of the three main classes of phraseological units (PUs): collocations, idioms, proverbs and routine formulas. In fact, the extract includes a total of 30 PUs distributed among the following categories:

Collocations: prevailing attitude; Social Security \& Medicare; current and future 
retirees; the Social Security trustees; make it clear; how bad the prospects have become; the Social Security trust fund surplus; past projections; overly optimistic; Medicare's hospital insurance fund; Social Security, Medicare and all other federal, state, and local government programs; make fiscally sound; labour income; income and excise taxes; IDIOMS \& METAPHORS: howling will eventually be heard, will run out of money, the oldest baby-boomers, will hit zero, around the turn of the century, the burden on future generations, will grow astronomically, a "wakeup call" study, strong medicine will be required, a $12 \%$ cut, a $12 \%$ rise, kick the dogs.

PROVERBS: Let sleeping dogs lie; the longer the wait, the sharper the bite will be. Routine Formula: Wish them luck.

The passage was also chosen according to the kind of conceptual metaphors that inspired its idioms (and proverbs), especially animal images and others related to the field of medicine, which exemplify the second main economic conceptual metaphor that I support, ECONOMY IS A LIVING BEING ${ }^{6}$. The extract also shows inanimate images that answer to the first main economic conceptual metaphor I have considered: ECONOMY IS AN INANIMATE OBJECT (Fraile Vicente 2005).

The idioms in the sample text present a hybrid nature according to the character of business English that mixes peculiarities of the general language and of the specialized languages. Certainly, most of these idioms are dead metaphors from everyday language or fields related to economics that are given a new specific sense that is understood in the context (Henderson, 2000: 172). Nevertheless, there are also "active image" metaphors which are innovatory and poetic (Backhouse et al, 1993: 7). Therefore, these constructions constitute examples of technical, semi-technical and general vocabulary ${ }^{8}$.

I told the students to translate the passage and to answer some questions that had been selected carefully so that they were a guide to the main translation problems they would meet and the type of lexicographical resources they could find their solution in. Before beginning the translation, the students were given, as an aid, some instructions about the origin of the text, its subject and structure:

This text has been taken from the issue of October 1995 of the economics journal FORTUNE. It talks about the financial problems that Social Security and Medicare are going to have in the future when mass retirements begin, and those organisms do not have enough money to finance them. In your translation, it is important to keep the images more relevant to the structure of the text. Notice that they appear at the beginning and end of the fragment giving it a circular character.

The analysis of the sample text contained two parts: the search for idioms in paper dictionaries and digital glossaries. In the first phase, the working group had to translate the extract with the help of different dictionaries: 10 general, 10 phraseological and 14 of business; monolingual, bilingual and multilingual (see bibliography); and to answer four questions whose purpose is to ratify the following hypotheses: 
1. Underline in the text the groups of words that are more difficult to translate (a minimum of 10). The question was aimed at checking the existence of a high proportion of idioms among the financial expressions which pose more problems to inexperienced translators.

2. What are these expressions? Why are they so difficult to translate? This one tried to show that it is not easy for beginner translators to recognize idioms, explain their syntactic-semantic peculiarities and to transfer them into another language.

3. What complications have you had in finding these expressions in the dictionaries? It wanted to find out some of the traditional deficiencies in the lexicographical resources as regards their treatment of idioms.

4. Which type of dictionary is more useful in the translation of these constructions, general (monolingual, bilingual), phraseological, or business (monolingual, bilingual, multilingual)? This query attempted to value the kind of dictionary which provides more syntactic-semantic information with idioms, structures it more systematically and offers users more flexible access to data.

In the second stage, students had more time to work individually to find the challenging expressions in a selection of 15 digital glossaries (see bibliography), to round off the translation and to solve the following questions:

1. Show the steps you have taken to find the digital resources you have used to solve the translation problems in this text. This question tried to find the different types of digital resources (glossaries, databases) that students used to improve the translation of the expressions.

2. Look up some of the following constructions ${ }^{9}$ in the suggested glossaries ${ }^{10}$ and tell which expressions you have found more frequently, group a) or b), and which glossaries offer better results. This question was aimed at guiding translators towards concrete glossaries where they would find the lexical units given which were distributed into two groups (idioms and literal collocations) so that they noticed the hybrid nature of the language of economics.

3. Write the translations of the constructions that you have improved with the help of those digital resources. This task had the purpose of checking whether the translation versions improved after this part of the test were idioms or more technical collocations.

The exercise ended with a comparative analysis of the treatment of idioms in the lexicographical resources in paper and digital format, so that beginner translators valued the advantages and disadvantages of each of these layouts in the access and structuring of phraseological information. 


\section{Results and discussion}

\subsection{Analysis of the translation of the sample text idioms}

The method that I followed to analyze the translation of idioms was to firstly study the equivalents included in the lexicographical resources, to compare them with those the students offered and, if necessary, to complete them with my own version. The purpose of this analysis was to check whether the beginner translators' mistakes were due to incomplete dictionary versions, and if so, to what degree.

I looked up idioms according to the general lemmatization tendencies observed in dictionaries: the idiom is looked for in the entry of the first noun and, afterwards, in that of the first verb. I used some monolingual (DAEM) and phraseological (DFEM) dictionaries in Spanish to check the possible Spanish translations of the English idioms. Equally, with those specialised works that include definitions in Spanish plus their equivalents in English, and which contain a final English-Spanish index (DTFI, DEF, DCNE), I looked up the keywords of the original English idiom in that index first, and then, I checked the Spanish expression that is indicated.

As I have recommended before, from the point of view of translation, it is better to maintain those metaphors which are relevant to the conceptual structure of the text. By doing this, translators have to take into account that the sample text is built up around a conceptual metaphor, based on animal images related to the canine world, that appears in four of the phraseological units considered: let sleeping dogs lie; howling will be heard; to kick the dogs; the longer the wait, the sharper the bite will be. The last two constructions are not lexicalized but constitute external modifications in context (Corpas Pastor, 1996b: 233) of the first idiom, which have the purpose of emphasizing its expressiveness and bringing to mind, at the same time, the literal and figurative meanings of all the images implied. Those idioms are strategically placed at the beginning and end of the passage giving it a close circular character. The writer plays with the polysemous meanings of these terms that in a literal sense refer to dogs, wolves and their typical actions and, in a figurative sense, designate human qualities or activities related to the financial world. As there are no similar idioms in Spanish which play with canine images, I suggest turning to modulation in the translation of these constructions to transmit the same meaning with other metaphors:

1. Let sleeping dogs $l i e^{11}$ and the final metaphor kick the dogs contain the image dog that shows the animal conceptual metaphor prevailing in the text. The first expression is a dead metaphor from the general language that is identified as idiomatic only in one of the general works (OALDCE), whereas the general bilingual dictionaries offer an obsolete translation equivalent: "más vale no meneallo" (OSD, CSD, LAROUSSE). This treatment may make students translate the construction literally, or result in examples of overtranslation. I prefer paraphrases such as "mejor no remover el asunto" (OSD), or those offered by the phraseological dictionaries (DMIN) "dejar las cosas como están”, 
"no remover cosas pasadas", "evitar complicaciones" which, at the same time, provide good examples of the contextual use of the idiom (ODCIE), and information on its morphological variants (COBUILDID announces that it can be shortened to a sleeping $d o g$ ). In this case, the students proposed more accurate versions than the lexicographical resources, other paraphrases ("dejar todo como está y no crear problemas", "es mejor callarse que empeorar las cosas"), and right modulations ("esconder el bulto", "agua que no has de beber déjala correr", "dejar la fiesta en paz", "no echar más leña al fuego") that may be used to bring about plays with images similar to those in the original text.

2. The second figurative expression (kick the dogs) uses the previous image (dog) creatively to build up an "active image" business metaphor that is not found in dictionaries ${ }^{12}$. That is the reason why some of the students did not recognize its figurative meaning, and translated it literally. You only discover the double sense of the construction thanks to the specialized dictionaries that define $d o g$ as: "a product or business which has a low relative market share in a market with a low rate. As it is probably acting as a drag on company profits, it should be a candidate for disvestment" (LDBE). To translate properly, we have to conjugate the previous sense with the idea transmited by kick: "librarse con una patada de algo o alguien que no es apreciado" (OSD, CSD, LAROUSSE), which refers here to the financial operations that do not yield a profit. As it could be expected, financial glossaries cite more details about this image (Investopedia, MoneyeXtra). Moneyextra even includes a sequence from a film that exemplifies its economic sense:

$A$ 'dog' is a company not to invest in! It's in bad shape, probably has management problems and its share price is 'sagging'. In the film, 'Wall Street' staring Michael Douglas, one character remarked about a share "It's a dog with fleas," when offered it by a stockbroker!.

For the translation of kick the dogs, the young translators provided modulations that allow the extract to keep it's circularity: the translation of the first idiom "esconder el bulto" can interact with "sacar a la luz" (which show a play with darkness/light), while "no echar más leña al fuego" can refer to "poner manos a la obra" (to act/ not to act). Personally, I would translate let sleeping dogs lie with the idiom "no revelar el pastel" and would choose "tirar de la manta" for kick the dogs because both expressions can be considered as equivalents to the English ones, that are used in this context with the sense "not to tell what should be secret because it could cause problems", but apart from that, the second one emphasizes that the action is deliberate.

3. Howling ${ }^{13}$ (in Howling will eventually be heard) is a common language metaphor. The general bilingual dictionaries recommend partial equivalents that suggest the application of this image to the business context to refer to the cries of protest that the bad 
management in Social Security and Medicare are going to raise: "dar alaridos/ aullidos/ rugidos/ bramidos de protesta" (OSD, CSD y LAROUSSE). Our apprentice translators did not always know which version to choose from so many equivalents and tended to interpret the expression literally, or to exceed the strength of their translation. Nevertheless, they also offered a modulation with two images not present in the original text ("si el ambiente se caldea, esto saldrá a la luz") that could be used as compensation.

4. The longer the wait, the sharper the bite will be looks like a proverb from the general language whose end would have been modified creatively, but this lexical unit is not found like that in any reference book. Therefore, bite constitutes another "active image" metaphor that refers to the business meaning of $d o g$ so that the whole expression applies in a figurative sense to the bad future that awaits the public funds. Instead of literal versions or overtranslations, I recommend modulations like those proposed by the students (“cuanto más esperen, más dura será la caída/ más fuerte será el golpe”, “cuanto más larga sea la espera, mayor será el daño").

It is also important to keep metaphors from everyday life in translation, medicine included, (the oldest baby-boomers, around the turn of the century, a "wakeup call" study, to grow astronomically, strong medicine will be required) that describe the factors implied in the business development like elements outside that process, like an illness or a burden that can be controlled with several measures. These are semitechnical expressions from the general language which are quite frequent in business texts, or constructions which have some meanings in the common language and some others in specialized fields related to economics:

5. Baby boomers (in the oldest baby-boomers start to retire) is a semitechnical idiom (from statistics according to EURODICAUTOM ${ }^{14}$ ) THAT, DESPITE ITS SPECIALIZED NATURE, CAN BE FOUND IN THREE GENERAL DiCTIONARIES (A MONOLINGUAL, OALDCE, and two bilingual, OSD y CSD) and a specialized dictionary (HBD) with the meaning "los niños nacidos en época de un boom de natalidad, especialmente en los años 60 que siguieron a la Segunda Guerra Mundial”. Of course, the on-line resources offer the better results, it is found in four specialized glossaries ${ }^{15}$ and in the terminological database EURODICAUTOM. The glossary AMOSWEB:GLOSS*ARAMA provides information related to the economic content of the extract: "entre los años 1946 y 1960 en Estados Unidos nacieron más personas que en otros periodos similares; estos individuos constituyen una parte importante de la población que ha contribuido a los beneficios de la seguridad social con sus impuestos (en los años 80 y 90). Sin embargo, cuando estos ciudadanos se jubilen alrededor de 2020, demandarán mayores pensiones a la seguridad social". As there is no semantic information that specifies the status of the expression in Spanish, the students tended to keep the borrowing in translation ("los baby-boomers más mayores", "los primeros que nacieron en la época del baby-boom"), or to use exceedingly long paraphrases ("los nacidos en la última época de crecimiento 
demográfico empezarán a jubilarse en masa"), when it is much better to clearly explain the sense of the idiom "los nacidos del primer boom de natalidad", "las primeras jubilaciones en masa".

6. Around the turn of the century is a figurative expression from the general vocabulary, a dead metaphor that only appears classified as an idiom in a phraseological dictionary (NTC) and in two monolingual general ones (OALDCE, CoBUILD), which define it as "the period of time covering the end of the century, decade, year, you are referring to and the beginning of the next one: These issues have preoccupied sociology since the turn of the century" (COBUILD). The bilingual general dictionary OsD interprets it as "a finales de siglo" but it can also be understood as "al principio del siglo" or "a mediados del siglo". The semantic indefiniteness of this characterization causes the insecurity observed in translations, the close equivalences suggested by students ("para el final del siglo", "al acabar el siglo", al cambiar de siglo", "con/ en el cambio de siglo", "antes/ alrededor del cambio de siglo") or modulations that show changes in time perspective ("a comienzos del próximo siglo", "para el comienzo del nuevo siglo").

7. A wakeup call $^{16}$ constitutes a semitechnical idiom that EurodicAUTOM places in the field of telecommunications where it is translated as "servicio de despertador". This interpretation originates some of the erroneous literal translations of the students, but is not adequate to our context where it is used metaphorically ( wakeup-call study). In general, the reference works are not sufficient to understand the figurative sense of the expression. This sense is just included in some definitions of wake up in general dictionaries ("algo que te hace despertar ante una situación frente a la que estabas pasivo” - COBUILD, CSD, LAROUSSE, ODCIE) and in one of the phraseological works that shows the whole construction ("shows people into taking action about a difficult or dangerous situation" - COBUILDID). The partial equivalents proposed by the young translators are too long:

"una llamada de alerta publicada en un estudio", "una llamada de alerta en forma de estudio", "un estudio realizado como llamada de atención", "un estudio llamada de atención".

For that reason, I decided to translate the idiom with the modulation "un estudio revelador/ premonitorio" or using those suggested by the young translators ("un estudio alarmante", "un estudio revela que") or even their paraphrases ("un estudio estatal advierte que", "según un estudio de emergencia").

8. The use of the adverb in grow astronomically ${ }^{17}$ gives a hyperbolic character to this idiom from the general language that is not included in any dictionary, just the general works show the use of the verb to mean "the development of a business or company" (OAldce, Ldoce, Cobuild). As students pointed out, it can be translated into Castilian with total equivalences ("crecerá de manera astronómica/ astronómicamente") and 
modulations, some with adverbial phrases that keep the initial hyperbole ("crecerá vertiginosamente / enormemente / de forma desorbitada", "se disparará".

9. The semitechnical term "medicine" is used figuratively in strong medicine will be required to refer to the remedy of economic ailments, a meaning that is only found in one of the bilingual general dictionaries (OSD). In spite of the fact that some of the students translated the unit literally, in general, they put forward effective translation proposals, the total equivalence "se necesitará una medicina (más) fuerte", the partial equivalence "se necesitará un remedio poderoso", the modulation "se necesitará mano dura" and the paraphrase "es necesario adoptar medidas drásticas".

The rest of the metaphorical expressions in the text use inanimate images to describe fluctuation in finances. Again, it can be noticed that most of these idioms take an economic sense, though they come from the general language or fields close to economics. That is why you have to use the information included in the dictionaries of phraseology and business to polish translations:

10. Run out of money in The Social Security trust fund surplus will run out of money comes from the general language phrasal verb run out of something that can be used with certain substances such as money to indicate that they are finished (OALDCE, LDCOE, CoBuILD). In the translation of this idiom, I advised against the use of the partial equivalences suggested by some of the specialized works because of their too colloquial register "estarán sin blanca", "no tendrán un duro" (ESBD, DifDDEA). However, it can be translated with the students' modulation "los fondos se congelarán", and with the paraphrases of the bilingual general dictionaries "los fondos se habrán acabado/ agotado" (OSD, CSD, LAROUSSE) and of the specialized dictionaries "habrán agotado sus existencias", "no tendrán dinero" (BSD, ESBD).

11. The numerical nature of to hit zero makes this general language idiom applicable to habitual questions and to those related to finances alike. No resource shows the whole expression, though three general dictionaries, two monolingual and one bilingual, point out that it refers to "a particularly high or low point on a scale" (LDCOE, COBUILD, OSD). I translated it with the partial equivalences "los fondos públicos estarán a cero", "bajo mínimos", or the modulation of our amateur translators: "caerán en picado".

12. Burden is a word from the general language, as it is certified by its eleven apparitions in the dictionaries consulted. Just three of them (OALDCE, CSD y LAROUSSE) indicated a possible figurative meaning, but the rest (OALdce, Ldoce, Osd, DTeFC, DBeE) related the expression to the metaphorical meaning it has in the burden on future generations $^{18}$ to designate "una carga o responsabilidad molesta para uno", (CSD) more specifically "impositiva o fiscal" (OSD, BBI, DTEFC, BSD, DBEE). Students translated it as "carga (fiscal)", "peso" (total equivalences), "responsabilidad” (paraphrase). 
13. Cut $\mathrm{y}$ rise are the semitechnical ${ }^{19}$ expressions that appear more frequently in the reference works (fourteen times). In a 12\% cut in Social Security and health benefits, cut implies "a reduction in size, length, amount: price/job/tax cuts" (OALDCE) and can be translated as "un recorte/ una reducción del $12 \%$ en los beneficios de la seguridad social y la sanidad pública" (OSD, CSD, DTEFC, BSD, DBEe, HBD). In the same way, its antonym rise ${ }^{20}$ in a $12 \%$ rise in income and excise taxes should be transferred as "un recargo" ${ }^{21}$ (EURODICAUTOM) or "una subida/ aumento/ ascenso del 12\% en el impuesto sobre la renta" (OAldce, Cobuild, Osd, Dtefc, Bsd, Dbee, Def, Hbd), possibilities that were considered by the young translators.

\subsection{Lexicographical limitations ratified by the results of the translation test}

The results obtained in the two phases of the test confirm in general the hypotheses that were my starting point. The search in paper dictionaries leads to the following findings:

1. Most students recognized that the text terminological difficulties correspond to two types of lexical units: idioms (that they call set phrases $^{22}$ ) and specialized terms. They agreed that translation problems arise, in the first place, because a literal version may not be suitable, as these metaphorical expressions do not have a direct equivalence in Spanish (students also pointed out the colloquial or ironical character of some of the idioms) and, secondly, due to the translator's ignorance about the specialized field.

2. For a high percentage of students $(37 \%)^{23}$, idioms represented half (or almost half) of the expressions they underlined as difficult to translate. This proves that indeed idioms constitute a large part of the translation problems related to the language of business ${ }^{24}$. Those translators who had more time to complete the exercise corroborated this tendency with a high proportion $(65 \%)^{25}$.

3. In spite of the fact that more than half the students (54\%) make out a big part of the text idioms $(5,6,7$ or 9 out of a total of 14), there is still a high percentage of them (46\%) who were unable to recognize most of these expressions ${ }^{26}$. This proportion falls to $33 \%$ with the students that handed in a second translation ${ }^{27}$, though some idioms (will grow astronomically) were still not recognized by any of the students.

4. The young translators found it difficult to identify the exact elements that make up an idiom:

- They tended to shorten the expression and did not recognize it entirely. For example, they perceived let sleeping dogs lie as ${ }^{28}$ let sleeping dogs, *sleeping dogs lie, *sleeping dogs. There were even more extreme instances: *the sharper the bite will be, *sharper the bite will be, *sharper, the bite, *the bite will be, *the sharper, *the bite, 
*sharper. The general trend was to reduce the construction to the metaphor it showed (sleeping dogs, howling, baby-boomer, turn, burden, strong medicine, cut, rise, bite).

- The opposite trend of lengthening the expression and joining it incorrectly to the following or previous words is a less frequent error: if the idiom is the subject, a verb is added; the verb is fused with its complements, etc. (*strong medicine required, *a "wake-up" call study states, *hit zero around the turn of the century, *will hit zero around the turn of the century, *are trying to kick the dogs, *oldest baby-boomers ${ }^{29}$.

5. In spite of the students not recognizing the text idioms easily, $74 \%$ of them succeeded in properly translating many more idioms than the total number of expressions they considered difficult to translate, though only $43 \%$ accurately translated half (or more than half) of the text idioms ${ }^{30}$. Both percentages increased considerably among the students that handed in a second improved translation ( $90 \%$ and $87 \%$ respectively $)^{31}$. While idioms from the general language (will grow astronomically) were translated correctly even when its idiomatic nature was not recognized, business idioms needed more disambiguation, but the specialized dictionaries did not offer enough information on their use.

6. Most idioms presented in the sample test came from the general language (7 out of 14, $50 \%), 5$ were semitechnical vocabulary $(35.71 \%)$ and 2 were technical idioms from the field of economics (14.29\%). The hybrid nature of these idioms is related to the fact that the general dictionaries are the source that offers better results with idioms from a semitechnical register like that of the text analyzed:

- $\quad$ Idioms from the general language appear more frequently in the general dictionaries that even specify their economic sense, but do not indicate their idiomatic nature. In contrast, the phraseological dictionaries do not usually include these units.

- The semitechnical idioms are better explained in the specialized books (dictionaries, glossaries, terminological databases), but they can also be found in the general resources. In some cases, the phraseological dictionaries treat their idiomatic senses.

- $\quad$ The technical idioms are defined more in detail in the specialized resources. Even so, glossaries only contain 6 out of the 14 idioms studied, and those belong to the three linguistic levels mentioned. As a result, it could also be necessary to use the general resources to round off the translation of their semantic subtleties.

To evaluate all of these lexicographical resources, I took into account the number of idioms present in each of them, as well as the number of entries that offer the most useful information to successfully carry out the translation of idioms. In OSD I found the 13 expressions, in LDOCE and OALDCE 11, and in COBUILD, CSD and LAROUSSE 10, as opposed to the marks offered by the specialized dictionaries (DBEE 8 idioms; LDBE y DTEFC 7; BSD 6; Esbd 4; Dcne 4; DTfi and Dmee 1; DAem, CDB and Defie 0). These figures confirm the 
previous assumption that, on the whole, the general dictionaries presented better results than the specialized dictionaries in the translation of the idioms analyzed, and out of all the books, those published by Oxford University Press prevailed. The young translators also emphasized the usefulness of the bilingual resources for translation, both general and specialized (CORPAS PASTOR ET AL., 2001: 249-251). The phraseological dictionaries, contrary to what is expected, contained fewer of these idioms: ODCIE and NTC (3); DFEM (2); EI, LDEI, PDEI and DMIN (1).

7. The working group recognized having found the next lexicographical limitations in their search for translation equivalents of the text idioms (Fraile Vicente, 2005: §5.2):

- The expression was not identified as idiomatic, so that students did not recognize the kind of construction they were translating, ignored which dictionary could help them better in that task and tended to translate the construction literally.

- $\quad$ Some of the idioms did not appear in any of the dictionaries (kick the dogs):

o The inexperienced translators did not find some specialized idioms in the general resources or in business dictionaries, and if they did, the sense offered did not fit the translation context.

o They did not find many idioms in the phraseological dictionaries either, as they are not used to consulting that type of book that, besides, contained few entries.

- They did not know under which lemma they should look for the idiom (noun, verb), or in which part of the entry (they often had to scan through the many meanings in an article).

- Idioms did not appear complete in these works, this was so that students had to carry out several searches and mix several definitions to understand their meaning better.

- In general, students found the definition but not the translation of these constructions, in such a way that they needed two searches, first in a monolingual dictionary to understand the expression, then in a bilingual one to find its translation. However, the opposite process also appeared quite frequently: first they looked up the equivalent and later its explanation in a monolingual dictionary to improve the translation.

- Beginner translators did not always understand the definition of a technical expression from a monolingual specialized dictionary, as it was usually written in a formal register.

- $\quad$ Either several senses of a lemma had no corresponding translation equivalents, or students found the idiom translation but the version offered was obsolete, showed a different register or did not match the context.

- The bilingual specialized works did not usually include information which helped to choose among the possible translation equivalents of a particular idiom, or to differentiate the literal paraphrases from the idiomatic versions, in such a way that students had to follow the linguistic context and their common sense.

- They found discrepancies (different translation equivalents) either among different 
lexicographical resources, or between the two linguistic sections of the same dictionary.

In the second part of the test, our amateur translators had enough time to conduct more terminological searches, finish the translation and answer all the questions posed appropriately. The search in the digital resources offered the following results:

1. In spite of the fact that the young translators had enough time to complete the exercise and that they named many digital sources that could have helped them in translation, they did not use all of them:

Amongst others, they mentioned the next digital resources: compilers of search engines (Buscopio, Dogpile), search engines (Google), translation websites (Traduteca, СРТСвA), directories of dictionaries and glossaries, digital libraries (UNED), metadictionaries (Onelook.com), dictionaries (Lexicool, Tododoccionarios.com), glossaries (IULA), linguistic corpora.

2. The translations they improved thanks to the digital resources correspond more to technical expressions rather than idioms ${ }^{32}$; to 5 specialized collocations to be precise (income \& excise taxes, health benefits, trust fund surplus, labour income, Medicare) and only 2 idioms (baby-boomer y dog). The glossaries more highly valued by students, as they contain better terminological information were: Amo's World, Investorwords, Investopedia and, mainly, MoneyGlossary which also includes a definition, translation and references to several dictionaries. Finally, students concluded that the terminological base Eurodicautom offers very helpful information.

3. The glossaries' information also brought about errors of interpretation in the translation of the specialized collocations (health benefits, that is to say "prestaciones sanitarias", is interpreted as *baja laboral, *subsidio de enfermedad, *beneficios para la salud, *beneficios médicos), and of idioms (baby-boomer is translated as if it made reference to the infants when it applies to the elderly: *niños estadounidenses nacidos después de la II guerra mundial, *persona nacida después de la segunda guerra mundial; dog is transferred literally: *perro macho; and the translation of wakeup-call makes no sense: *estudio de rendimiento).

4.3. Types of translation mistakes, their relationship with the lexicographical treatment of business idioms

The students' versions show general translation mistakes of a syntactic nature, such as calques of English order (*bajo sus más pesimistas principios, *los ahora y futuros jubilados, *la predominante actitud de Washington), and lexical repetition (*los fondos ... habrán tocado fondo) but, mainly, semantic errors of a diverse nature: 
1. The use of invented words (*prevaleciente, *concevibles, *conceviblemente).

2. Colloquialisms and other errors of expression (*cómo de mal se han puesto las cosas, *jubilados ahora y en el futuro en un número mayor).

3. Wrong translations of specialized collocations which are conveyed with very long incomprehensible paraphrases:

Students refused to translate Medicare in Medicare's hospital insurance fund ("los fondos de la sanidad pública") which is conveyed as *El fondo de seguros del hospital Medicare, *Los fondos de los seguros de los hospitales del Medicare.

4. The main semantic errors, nevertheless, had to do with unfortunate translations of the text idioms which are based on traditional conceptions about the theory of translation which should be overcome (Fraile Vicente, 2005: §5.2):

- $\quad$ Translations carried out too literally. The expressions were not identified as idiomatic in the dictionary, so that students did not recognize their figurative meaning and used the literal target language expression which is more similar to the original idiom, as the examples below show (Corpas Pastor, 2000: 502). Nevertheless, literal translation can only be applied when each language and culture symbolizes experience in the same way and structures and meanings coincidence, which is rare (Vázquez-Ayora, 1997: 259):

o Let sleeping dogs lie $=*$ dejar dormir a los perros, *más vale no menear al perro, *a perro dormido no lo despiertes.

o Howling will eventually be heard $=$ *pero el aullido será escuchado.

o Strong medicine will be required $=*$ se requerirá inmediatamente una mayor cantidad de medicamentos, *se requerirán medicamentos eficaces.

o The longer the wait, the sharper the bite will be = *cuanto más larga sea la espera, más profundo será el mordisco, *cuanto más larga sea la espera, más certero y estudiado será el mordisco en el ataque.

- $\quad$ Cases of overtranslation and undertranslation. Dictionaries tend to offer partial translation equivalents as if they were total equivalents. Looking for equivalence at all costs, students sometimes exceeded in intensity, accelerated images, introduced connotations not present in the original, or destroyed its semantic nuances to the point of conveying the opposite meaning (as in the translations for Kick the dogs below). This is the reason why it is important that the lexicographical resources describe the semantic differences which are relevant between the original and translated versions (Corpas Pastor, 2000: 492):

o Let sleeping dogs lie $=*$ dejemos que la mentira de los buitres/ lobos acechantes resuma...

o Howling will eventually be heard = *pero el estruendo acabará por oírse, *pero 
el clamor se hará patente.

o Baby-boomers $=*$ los viejos recién nacidos, *las personas más mayores en edad de procrear.

o To kick the dogs $=*$ remover la mierda, *están intentando deshacerse empero de los molestos caninos.

- Use of unnecessary paraphrases. The specialized dictionaries tend to explain the meaning of idioms instead of looking for a suitable figurative expression in Spanish, such as a modulation. An abusive use of paraphrases leads to distortions of the text similar to those caused by an erroneous application of the literal translation. To translate the recreation of the image dog in kick the dogs and the longer the wait the sharper the bite will be, it is better to use a modulation that avoids introducing strange elements into the Spanish language and still maintains a figure. Instead, our translators, offered long lifeless paraphrases such as the following:

o kick the dogs = "están intentando dar con alguna solución", "intentan tratar el problema".

o Howling (en Howling will eventually be heard) = "los gritos/ las protestas se escucharán", "empezarán a escucharse voces en contra de esta actitud", "las quejas se harán patentes".

o The longer the wait, the sharper the bite will be = "cuanto más esperemos, más serios serán nuestros problemas/ peores serán las consecuencias”.

- Use of unnecessary borrowings. As dictionaries do not clearly explain the status and meaning of borrowings, these are kept in translation when the construction could have been paraphrased in Spanish. It is widely accepted that borrowings bring about neologisms that revitalize phraseological units (they can create an expressive effect or add local colour), but they can manifest a lack of competence and can result in mistakes being made as well. That is why I believe that the meaning of idioms such as baby-boomers, that has no equivalent in Spanish, should be explained ("la explosion demográfica de los 60", "los nacidos en época de fuerte crecimiento demográfico"), instead of maintaining the original word in the translation as in the next erroneous versions presented by my students:

*el más reciente baby-boom, *el baby-boom más antiguo, *los que nacieron en el más antiguo baby-boom, *el más antiguo de los baby-boom, *el más mayor/viejo baby-boom, *los hijos más viejos del baby-boom. 


\section{Conclusions: Suggestions to improve the lexicographical treatment of business idioms.}

Metaphors and idioms are indeed some of the elements that make business discourse difficult to understand and to transfer for beginner translators but, at the same time, they contribute to the construction of the financial conceptual system and shape the semitechnical nature of this domain.

The students' translation errors analyzed are highly motivated by a limited lexicographical treatment of business idioms, based on traditional conceptions about the theory of translation: dictionaries look for equivalence at all costs, present translation versions as if they were functionally equivalent when they are not so, or paraphrase the construction when it would be better to use a more expressive modulation.

The best way to translate business idioms (and idioms in general) is to look for another figurative expression in Spanish which transmits the same idea and shows equal frequency (a total or partial equivalence or a modulation), or if this is not possible, to use a literal paraphrase that explains the meaning of the construction.

The main deficiencies in the treatment of idioms that the general and specialized dictionaries should pay special attention to, can be summarized as their lack of organisation in the criteria for idiom selection and inclusion, as regards the place of the dictionary where these constructions should appear, the way they should be lemmatized, and the type of lexical information that should be offered with them.

In this respect, business dictionaries should be more systematic when it comes to the place of the book where idioms are shown (macrostructure or microstructure) and the element that is taken as the lemma. In fact, idioms should be included as independent lemmas in the macrostructure, and labels should be used to identify them, so that users would be able to differentiate them from other types of phraseological units, to recognize the whole construction and its possible structures.

It will always be difficult for the lexicographical resources to reproduce idioms and figurative expressions, since they are in a continuous process of creation and fossilization. Nevertheless, to be a useful resource for the translator of business idioms, most specialized dictionaries should meet two complementary needs, text comprehension and production, as the translator must be able to understand the source text and to codify it in the target language, in such a way that it looks natural to the L2 reader. This implies that LSP dictionaries should include encyclopaedic and linguistic knowledge, should offer more syntactic semantic and pragmatic information concerning idioms and it should be structured more systematically (as some do):

- A definition which provides the conceptual knowledge and the field specific notions

- A lexicon which comprises three levels of specialization (technical, semitechnical and general vocabulary); as well as the phraseological units (like the idioms studied, whose meaning is not always transparent and are difficult to predict in another language); contexts, examples of use, and other linguistic indications: grammatical category, subject field label, 
synonyms, antonyms, cross-references, variants; that are a help in the decision-making process that translation implies.

Moreover, the dictionary should base its entries on the conceptual structure of economics which is partly made up of the field conceptual metaphors:

- In the conceptual organization of a domain, you can observe all the concepts of a specialized field, the relationship between them (the place of the concept in the hierarchy), as well as the terms that derive from a particular concept. The conceptual structure of a domain guides the selection of the lexical units to be included in the dictionary, places each of them inside a structured set, and allows one to delimit their meaning, to associate terms and identify the most suitable equivalent in the target language (Gómez González-Jover \& Vargas Sierra, 2004: §5).

- If LSP dictionaries were organized conceptually, they would be able to derive their entries from the concept they were related to. This is especially important in the case of the idioms studied which are based on essential metaphors that can be included as concepts in the structure of the field of economics. A conceptual metaphor is the common base between two languages that may bring about different images or realizations in each of the languages. Any classification of linguistic metaphors should, then, start from the types of conceptual metaphors, the mental associations that are their base. The analysis of linguistic contrasts based on metaphors can be extremely useful to describe the semantic fields of TL and SL idioms, to discover the abstract metaphorical models and the rich individual metaphors, to check the expressions which are closer in function and meaning, to differentiate the translation equivalents from the pseudo-equivalents.

The nuances of meaning closer to the economic register of the text were provided not only by the specialized resources, but also by the general works, as the information from the digital resources alone is not enough to identify idiom structures. The final comparative analysis of lexicographical resources in paper and digital format suggested the following advantages and disadvantages of these books in their treatment of business idioms:

- Dictionaries in paper are more reliable and easier to use, they offer more details (exemplify the expression and show it in a context), and are better for the everyday constructions and for idioms in general, or for a first search that will be later contextualized with a second quest in a specialized resource. Nevertheless, its coverage is more limited, information may not be updated, and the interrogation is slower if you have to conduct several searches, or resort to several books to consult different topics.

- The digital sources present results more quickly, they are frequently updated and may include several disciplines in just one resource. They are more useful to find technical expressions or neologisms and offer more links to related terms. 
However, it is important to check whether they are reliable as some have a temporal existence, do not always include the metaphorical constructions and may bring about erroneous translations.

\section{Notes}

1. I call them specialized languages, special languages or languages for special purposes (LSPS) (Sager et al., 1980).

2. This opinion should be qualified, idioms and metaphors are usually more abundant in English semitechnical business texts than in Spanish ones due to the power of explanation idioms have over non experts when it comes to explain highly complex terms, which is a common resource used by media writers in English and not so much by Spanish ones.

3. In this regard, it should be noticed that business and economics language is created mainly in the U:S: where this "nautical tradition" is not so present.

4. The literal translation of the more innovative economic metaphors, nevertheless, cannot be applied if there is a cultural dissociation between the languages considered.

5 . $51 \%$ of idioms are semiidiomatic, $37 \%$ transparent, and pure idioms are really scarce (0.0001\% or 1/1.000.000) (Moon 1998: 81-96). The text studied shows a high frequency of these units (12 idioms in a total of 237 words amounts to almost $6 \%$ of total frequency, and the presence of 12 idioms in a total of 30 phraseological units implies that around $40 \%$ of the de PUs contained in the fragment are metaphorical).

6. Animate metaphors follow a progression from the theory of evolution, to applied biology and social medicine.

7. Backhouse et al (1993: 7) recognize those metaphors inevitably based on the common language, together with those conventionalized in the economic analysis, and those of active image that are innovatory and poetic.

8. The economic discourse is made up of the following types of lexical units:

-technical vocabulary: terms used specifically in economics (cash flow, credit),

-semi-technical vocabulary: lexical units with a meaning in the general language and many others in LSPs related to economics (spread, margin),

-general vocabulary: words from the general language which acquire specialized senses through metaphorical processes and are used in economics (surge, rise, hike, dismiss) (Fuertes Olivera et al, 2002: 122).

Nevertheless, the borders are often blurred and not clear, "credit" is also a semi-technical word and "margin" has very technical meanings.

9. The constructions are these: a) dog, baby boomer, a wake-up call study, cut, rise; b) Medicare, trust fund surplus, make fiscally sound, labour income, health benefits, income and excise taxes.

10. The glossaries suggested are Amo's World Economic Glossary, The American Stock Exchange, Moneyextra Glossary, InvestorWords.com, Investopedia.com, MoneyGlossary.com and the term base Eurodicautom.

11. "Not to look for trouble on purpose; both interrupt or trouble a person, situation, etc., when this is likely to cause disorder" (Ldei).

12. In Spanish, the term "empresa perro" is used by economists but "perro" in Spanish does 
not connote the same as in English, only in the sense of "perezoso, vago".

13. " 1 . If an animal such as a wolf or a dog howls, it utters a long, loud crying sound. 2. If a person howls, they make a long, loud cry expressing pain, anger or unhappiness: She heard the child howling at his mother..." (Cobuild).

14. "The period following World War II from 1947-1961 was marked by a dramatic increase in fertility rates and in the absolute number of births in Canada, the USA, Australia and New Zealand" (Eurodicautom).

15. Amosweb:gloss*arama, The American Stock Exchange, MoneyGlossary.com, InvestorWords.com - Investing Glossary.

16. "1. If you have "a wake-up call", you arrange for someone to telephone you at a certain time in the morning so that you are sure to wake up at that time. 2. A wakeup call shows people into taking action about a difficult or dangerous situation". (Cobuild).

17. "If you describe an amount as astronomical, you are emphasizing it is very large indeed. Astronomically - He was astronomically wealthy...House prices had risen astronomically" (CobuildEdal).

18. "7. A financial/tax burden. 8. A burden on (he became a burden to his family)" (Bbi).

19. Eurodicautom notes that they come from economics and statistics.

20. "An increase in quantity, price, demand: A $25 \%$ rise in the price of oil" (Ldoce).

21. "Se habla de 'aumento' o 'acrecentamiento' referido a los precios; si se refiere al valor de una propiedad se trata de 'plusvalía'; mientras que si se trata de impuestos es 'recargo' (Eurodicautom)".

22. This fact reflects the terminological confusion involved in phraseology. There is not jet a clearly established term to name the discipline and each of the units which should be the object of its study.

23. Thirteen students out of 35 included idioms among the expressions they found difficult to translate.

24. In the first one hour session, just $15 \%$ of the students (that is to say 5) were able to finish the translation and just 26\% (9) answered the questions. In the second part of the test, nevertheless, $90 \%$ of the students (31) completed the translation and the questions.

25. For 20 out of the 31 students that hand in the second part of the test, idioms constitute half (or more than half) of the difficult expressions.

26. Eight per cent of the students discovered 9 idioms; $46 \%$ recognized 5,6 or $7 ; 32 \%$ underlined 1, 2, 3 or 4; and $14 \%$ did not distinguish any of them.

27. Exactly 8 students out of 31 were unable to recognize most expressions after the second part of the test.

28. The asterisk $(*)$ is used all over the article to show erroneous sentences or translations.

29. Going to extreme cases like that of the student who underlined as expression difficult to translate a whole sentence that contained a specialized collocation and two idioms: Medicare's hospital insurance fund will hit zero around the turn of the century.

30. That is to say 26 and 15 students out of 35 accurately translated half (or more than half) of the text idioms.

31. In the second part of the test, 28 students succeeded in properly translating many more idioms than the total number of expressions they considered difficult to translate, and 27 accurately translated half (or more than half) of the text idioms.

32. In fact, most students agreed that glossaries were more useful to translate those expressions in group $b$, which included the specialized collocations, than to transfer the idioms in group a. 
Certainly, these resources showed adequate translations of specialized collocations such as: Medicare $=$ sistema público de sanidad, sanidad pública, trust fund surplus $=$ fondos de financiación de la seguridad social, make fiscally sound $=$ sanear, labour income $=$ sueldo, health benefits $=$ la sanidad pública, income and excise taxes = impuesto sobre la renta.

\section{References}

\section{General monolingual dictionaries:}

1. (ClAve) - Clave. Diccionario de uso del español actual (1997) Madrid: Ediciones S.M.

2. (COBUILD) - Collins Cobuild Dictionary of the English Language (1987) Collins.

3. (COBUILDEDAL). Collins Cobuild English Dictionary for Advanced Learners (2001) Glasgow Harper Collins Publishers.

4. (DUE) - Moliner, María (1983): Diccionario de uso del español. Madrid: Gredos.

5. (Ds) Diccionario Salamanca de la lengua española (1996) Editorial Santillana y Universidad de Salamanca.

6. (LDOCE) - Longman Dictionary of Contemporary English (1990 \& 1995) London: Longman.

7. (OALDCE) - Oxford Advanced Learner's Dictionary of Current English (1995) Oxford: OUP.

\section{General bilingual dictionaries:}

8. (CSD) - Collins Spanish Dictionary (1999) Glasgow\& New York: Harper Collins.

9. (LAROUSSE) - Diccionario Moderno Español-Inglés, Inglés-Español (1993) Paris: Larousse.

10. (OSD) - The Oxford Spanish Dictionary (1994) Oxford: OUP.

\section{Phraseological dictionaries:}

11. (BBI) - Benson et al. (1997 [1986]): The BBI Dictionary of English Word Combinations. Amsterdam/ Philadelphia: John Benjamins Publishing Company.

12. (CoBuILDID) - Moon, Rosamund (1995): Collins Cobuild Dictionary of Idioms. Collins.

13. (DFEM) - Varela, F. \& H. Kubarth (1994) Diccionario fraseológico del español moderno. Madrid: Gredos.

14. (DIEM) - Carbonell Basset, Delfín (2004): Diccionario inglés y español de modismos. (Las frases que Ud. necesita) (A Spanish and English Dictionary of Idioms. The Phrases you Need). Barcelona: Ediciones del Serbal.

15. (DIFDEA) Diccionario fraseológico documentado del español actual: locuciones y modismos españoles. Manuel Seco (coord.) (2004) Aguilar: Madrid.

16. (DMIN) Torrents del Prats, A. (1997): Diccionario de modismos ingleses y norteamericanos. Juventud: Barcelona.

17. (EI) - Seidl, Jennifer (1990): English Idioms. Oxford: OUP.

18. (LDEI) - Longman Dictionary of English Idioms (1979) Longman.

19. (ODCIE) - Cowie, A. P., Mackin R. \& I. R. McCaig (1984 \& 1987): Oxford Dictionary of Current Idiomatic English. Oxford: OUP.

20. (PDEI) - Penguin Dictionary of English Idioms (1986) Penguin. 
Monolingual dictionaries of business:

21. (CDB) - Pass et al. (1995): Collins Dictionary of Business, $2^{\text {nd }}$. ed., Glasgow: Harper Collins Publishers.

22. (DAEM) Diccionario Akal de economía moderna. Madrid: Akal Ediciones.

23. (LDBE) - Adam, J. (1989): Longman Dictionary of Business English, $2^{\text {nd }}$. ed., Essex: Longman.

24. (ODBE) Oxford Dictionary of Business English for Learners of English, A. Tuck (ed.) (1995), Oxford: OUP.

\section{Bilingual dictionaries of business:}

25. (BSD) - Business Spanish Dictionary: Spanish-English English-Spanish (1998) London: Peter Collin Publishing.

26. (DBEE) - Lozano Irueste, Jose $\mathrm{M}^{\mathrm{a}}$ (2001): Diccionario bilingüe de economía y empresa: inglésespañol, español-inglés. Madrid: Pirámide.

27. (DEF) - Tamames, R. \& S. Gallego (2002): Diccionario de economía y finanzas, $11^{\mathrm{a}}$ ed., Alianza: Madrid.

28. (DEFIE) - Ruiz de Canales, P. (2000): Diccionario económico-financiero inglés-español. Madrid: Universitas.

29. (DTEFC) - Alcaraz Varó, Enrique \& B. Hughes (2002): Diccionario de términos económicos, financieros y comerciales. Inglés Español, Español-Inglés, $2^{\mathrm{a}}$ ed., Barcelona: Ariel Referencia.

30. (DTFI) - Mochón Morcillo, F. \& R. Isidro Aparicio (1998): Diccionario de términos financieros y de inversión, $2^{\mathrm{a}}$ ed., Madrid: McGraw-Hill.

31. (ESBD) - Gil Esteban, R. (2000): English-Spanish Banking Dictionary, Diccionario bancario español-inglés. Madrid: Paraninfo.

32. (HBD) Harrap's Business: Dictionary/Diccionario: English-Spanish, Español-Inglés, Teresa Álvarez (ed.) (2004) Harrap Edimburg.

\section{Multilingual dictionaries of business:}

33. (DMEE) - Diccionario multilingüe de economía y empresa, español-inglés, inglés-español; español-francés, francés-español; español-italiano, italiano-español y español-alemán, alemánespañol, (2000) Madrid Verbum.

34. (DCNE) - Diccionario capital de la nueva economía, Elosua y J. Plágaro (eds.) (2000) Madrid LID Editorial Empresarial.

\section{Financial glossaries:}

1. Oasis Management ${ }^{\circledR ' s}$ Comfrehemssive Fänanyial Gldssafy and Rerivatives (Contiprehemsive) (http://www.oasismanagement.com/glossary)

2. The Biz/ed Glossary and Diagram Bank (http://www.bized.ac.uk/glossary/) y (http://bized.ac.uk/virtual/economy/library/glossary)

3. Diccionario financiero de la bolsa de Valencia (http://www.bolsavalencia.es/Diccionario)

4. Amo's World Economic Glossary (ECONOMIC GLOSS*arama) 
(http://www.amosweb.com/gls)

5. NY Times Glossary of Financial and Business Terms (http://www.nytimes.com/library/financial/glossary/bfglosb.htm)

6. Moneyextra Glossary (Moneyworld) (http://www.moneyworld.co.uk/glossary)

7. The American Stock Exchange (http://www.amex.com)

8. Yahoo! Financial Glossary (http://biz.yahoo.com/f/g/g.html)

9. Glosario de finanzas. Duke University (Campbell R. Harvey's Hypertextual Finance Glossary) http://www.duke.edu/ charvey/fintb.htm)

10. MoneyGlossary.com (http://www.moneyglossary.com)

11. InvestorWords.com - Investing Glossary (http://www.investorwords.com/)

12. Investopedia.com(http://investopedia.com/dictionary)

13. Business Glossary (EN<->ES) (Business Spanish-English Glossary) (http://www.ctv.es/USERS/amiles/directsearch.htm) (http://www.lexicool.com/dlink.asp?ID =0YT1WJ5788\&IL =3\&L1 =09\&L2=29\&CA =09)

14. Tradition/Axone Financial Terminology Database - Axone Services and Developpement SA and Viel Tradition Group (Switzerland) (http://tradition.axone.ch)

15. Internacional Monetary Fund (IMF) Terminology - A Multilingual Directory. (http://www.imf.org/external/np/term/index.asp?index=eng\&index_langid=1)

16. (http://www.imf.org/external/np/term/index.asp)

\section{General bibliography:}

Alcaraz Varó, E. (2000): El inglés profesional y académico. Madrid: Alianza Editorial.

Backhouse, R., Dudley-Evans, T. and W. Henderson (1993): "Exploring the Language of Economics". In W. Henderson et al. (eds.) (1993): Economics and Language, London: Routledge, 1-20.

Bhatia, V. K. (1993): Analyzing genre: language use in professional settings. London: Longman. Boers, F. (2000): "Enhancing metaphoric awareness in specialised reading”. English for Specific Purposes 19(2): 134-147.

Bononno, R. (2000): “Terminology for Translators: an Implementation of ISO 12620" . Meta 14(4), 646-624.

Cabré Castellví, T. (1993): La terminología: Teoría, metodología, aplicaciones. Barcelona: Antártida/ Empúries. . (1994): "Terminololgie et dictionaries". Meta, 34(4): 589-597.

. (2004): “La terminología en la traducción especializada”. In C. Gonzalo García y V. García Yebra (eds.) Manual de Documentación y Terminología para la Traducción Especializada. Madrid: Arco Libros, 89-125.

Charteris-Black, J. (2000): "Metaphor and Vocabulary Teaching in ESP Economics". English for Specific Purposes, 19: 149-165.

Charteris-Black, J. and T. Ennis (2001): “A comparative study of metaphor in Spanish and English financial reporting”. English for Specific Purposes, 20 (3): 249-266.

Corpas Pastor, G. (1996b): Manual de fraseología española. Madrid: Gredos.

Charteris-Black, J. Corpas Pastor, G., Leiva Rojo, J. M ${ }^{\text {a }}$ and J. Varela Salinas (2001): "El papel del diccionario en la formación de traductores e intérpretes: análisis de necesidades y encuestas de uso". In M. Ayala Castro (coord.) Diccionarios y enseñanza, Colección ensayos y documentos, Universidad de Alcalá, 239-261. 
Deignan, A., Gabrys, D. and A. Solska (1997): “Teaching English metaphors using cross-linguistic awareness-raising activities”. ELT Journal 51: 43-51.

Dobrzyñska, T. (1995): “Translating metaphor: Problems of meaning”. Journal of Pragmatics, 24(6): 595-604.

Fraile Vicente, E. (2005): Las expresiones idiomáticas en los diccionarios de economía. Estudio de su presencia y propuesta de codificación desde una perspectiva traductológica. Doctoral Thesis. University of Valladolid (Spain) (Unpublished).

Fuertes Olivera, P. and E. Samaniego Fernández (1998): "Metaphor and Motivation: a study of English informal phraseological units". Lexicology, 4(1): 35-59.

Fuertes Olivera, P. and M ${ }^{\text {a }}$ S. Velasco Sacristán (2001b): "The translatability of metaphor in LSP: Application of a decision-making model”. Revista Alicantina de estudios ingleses, 14: 73-91.

Fuertes Olivera, P. and I. Pizarro Sánchez (2002): “Translation and 'similarity-creating metaphors' in specialised languages: A corpus-based research on the translation of English metaphorical expressions into Spanish". Target 14(1): 43-73.

Fuertes Olivera, P., Arribas Baño, A., Velasco Sacristán, M ${ }^{\mathrm{a}}$ and E. Samaniego Fernández (2002): "La variación y la metáfora terminológica en el dominio de la economía". Atlantis. Revista de la Asociación Española de Estudios Anglo-norteamericanos, 24 (1): 109-128.

Gallego Pelegrín, J. (2004): “Prólogo”. In C. Gonzalo García y V. García Yebra (eds.) Manual de Documentación y Terminología para la Traducción Especializada. Madrid: Arco Libros, 1922.

Gómez González-Jover, A. y C. Vargas Sierra (2004): “Aspectos metodológicos para la elaboración de diccionarios especializados bilingües destinados al traductor". In www.toledo2004.net (Enquiry 1-6-04).

Henderson, W. (1994): "Metaphor and economics. In R. E. Backhouse (ed.) New Directions in Economic Methodology. London and New York: Routledge, 343-367.

. (2000): "Metaphor, Economics and ESP: Some Comments". English for Specific Purposes, 19 (2): 167-173.

Indurkhya, B. (1992): Metaphor and Cognition: An Interactionist Approach. Dordrecht: Kluwer Academic Publishers.

Kurth, E. N. (1999): “Altered Images'. Cognitive and Pragmatic Aspects of Metaphor Translation". In J. Vandaele (ed.) Translation and the (Re)Location of Meaning. Selected Papers of the CETRA Research Seminars in Translation Studies 1994-1996. Lovaina: CETRA, 97-116.

Lakoff, G. y M. Johnson (1980): Metaphors we live by. Chicago: University of Chicago.

Larson, M. L. (1989): La traducción basada en el significado. Buenos Aires: Editorial Universitaria de Buenos Aires.

Lerat, P. (1997): Las lenguas especializadas. Barcelona: Ariel Lingüística.

Lipka, L. (1990): An Outline of English Lexicology. Tübingen: Max Niemeyer Verlag.

Mason, M. (1990): "Dancing on air: Analysis of a passage from an economics textbook". In A. Dudley-Evans and W. Henderson (eds.) The language of economics: The analysis of economics discourse, London: Macmillan, 16-28.

Mayoral Asensio, R. (1999a): "Las fidelidades del traductor jurado: una batalla indecisa”. In M. Feria (ed.) Traducir para la justicia. Granada: Comares, 59-86.

Mc los key, D. (1983): “The rhetoric of economics". Journal of Economic Literature, XXI, 481-517. (1998): The Rhetoric of Economics. University of Wisconsin Press. 
Meyer, I. and K. MacKintosh (1994): "Phraseme Analysis and Concept Analysis: Exploring a Symbiotic Relationship in the Specialized Lexicon”. In Martin, W. et al. (eds.) Euralex 1994: Proceedings. Amsterdam: International Congress on Lexicography, 339-348.

Meyer, I., Eck, K. y D. Skuce (1997): "Metaphorical internet terms: A conceptual and structural analysis". Terminology, 4 (1): 1-33.

Montero Martínez, S. (2002): Estructuración conceptual y formalización terminográfica de frasemas terminológicos en el subdominio de la oncología clínica. Tesis doctoral. Universidad de Valladolid. (Available on line at http://elies.rediris.es/elies19/index.html).

Moon, R. (1998): "Frequencies and Forms of Phrasal Lexemes in English". In A. P. Cowie (ed.) Phraseology, Theory, Analysis and Applications. Oxford: Clarendon Press, 79-100.

Pearson, J. (1998): Terms in Context. Studies in Corpus Linguistics, 1, Amsterdam/Philadelphia: John Benjamins.

Sager, J. C., Dungworth, D. and P. F. McDonald (1980): English special languages. Wiesbaden: Brandstetter.

Samaniego Fernández, E. (1995): "La metáfora y los estudios de traducción”. In P. Fernández Nistal (coord.) Perspectivas de la Traducción Inglés/ Español, $3^{\circ}$ Curso Superior de Traducción. Valladolid: ICE, 91-118.

Tarantino, M. (1991): “English for science and technology: A quest for legitimacy". ESP, 10: 47-60.

Toury, G. (1995): Descriptive Translation Studies and beyond. Amsterdam/Filadelfia: John Benjamins.

Walters-York, L. M. (1996): "Metaphor in accounting discourse". Accounting, Auditing and Accountability Journal, 9 (5): 45-70.

Young, J. J. (2001): “Risk(ing) Metaphors”. Critical Perspectives on Accounting, 12: 607-625. (Available online at http://www.idealibrary.com)

\section{Appendix I. Sample Text}

Let sleeping dogs lie. That about sums up Washington's prevailing attitude toward Social Security and Medicare. But howling will eventually be heard, because both programs promise current and future retirees more than can conceivably be financed by workers.

Two recent reports - one from the Social security trustees and one from academia make it clear just how bad the prospects have become. The Social Security trust fund surplus will run out of money in 2036, the trustees report. But past projections have been overly optimistic. Under their most pessimistic assumptions, it's 2014 about when the oldest babyboomers start to retire. Medicare's hospital insurance fund will hit zero around the turn of the century. Clinton-style health care reform won't help much.

If nothing is done soon to make Social Security, Medicare, and all other federal, state, and local government programs fiscally sound, the burden on future generations will grow astronomically. In a "wakeup call" study for Merrill Lynch, economists Alan Auerbach of Penn and Laurence Kotlikoff of Boston University calculate that Americans not yet born would have to pay nearly all their labour income in taxes. Strong medicine will be required, they say - like a $12 \%$ cut in Social Security and health benefits and a $12 \%$ rise in income and excise taxes. Immediately. A few lonely Congressmen are trying to kick the dogs. Wish them 
luck - the longer the wait, the sharper the bite will be. (FORTUNE, Octubre 1995).

\section{Translation Proposal}

"No revelar el pastel" resume la actitud mayoritaria de Washington en materia de seguridad social y sanidad pública. Pero la medida va a seguir levantando protestas airadas porque ambos organismos prometen a los pensionistas, presentes y futuros, cantidades mayores de las que lógicamente podrán ser financiadas por los trabajadores.

Dos informes recientes, uno de la seguridad social y otro de la administración revelan los malos augurios para el futuro. Según el primero de ellos, los fondos de financiación de la seguridad social se habrán agotado para el 2036 y, aún así las últimas previsiones fueron optimistas. El segundo, más pesimista, sostiene que las primeras jubilaciones en masa empezarán en el 2014 y que para final de siglo los fondos de la salud pública estarán bajo mínimos. La reforma sanitaria al estilo de Clinton no parece que vaya a ayudar mucho.

Si no se hace nada para sanear la seguridad social, la sanidad pública, y el resto de los organismos locales y nacionales, la carga impositiva dejada a las próximas generaciones crecerá de manera astronómica. En un estudio revelador para Merrill Lynch, los economistas Salan Auerbach de la universidad de Penn y Laurence Kotlikoff de la de Boston advierten de que los americanos que todavía no han nacido tendrán que pagar casi todo su sueldo en impuestos y de que se van a necesitar medidas contundentes de inmediato, como un recorte del $12 \%$ en los beneficios de la seguridad social y la sanidad pública, y una

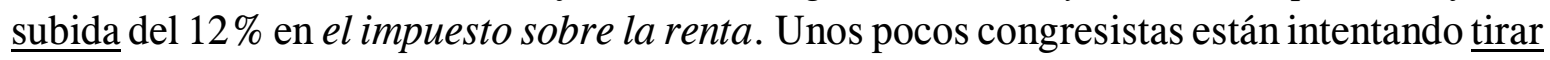
de la manta. Esperemos que tengan suerte porque cuanto más larga sea la espera, mayor será el batacazo. 